\title{
A preliminary investigation into the source of odor-cue production
}

\author{
MELANIE S. WEAVER \\ Emporia State University, Emporia, Kansas 66801 \\ DAVID A. WHITESIDE \\ University of Oklahoma, Norman, Oklahoma 73069 \\ and \\ WALTER C. JANZEN, SCOTT A. MOORE, and STEPHEN F. DAVIS \\ Emporia State University, Emporia, Kansas 66801
}

\begin{abstract}
Rats received a daily eight-trial double-alternation sequence of reward/nonreward in a straight runway during three phases of an experiment designed to investigate the source of reward/nonreward odor cues. Appropriately patterned responding was strongly established during the first (control, feet uncovered) phase, heightened during the second phase, when odors emanating from the feet were precluded, and returned to the original Phase 1 level during the third phase (feet uncovered). Even though the foot sweat pads do not appear to be a source for reward/nonreward odor, the present data do suggest that they may be a possible souree of odors that compete with reward/nonreward odor cues.
\end{abstract}

Fifteen years ago, Ludvigson and Sytsma (1967) demonstrated that rats were capable of appropriately mastering a double-alternation schedule of reward (R)/ nonreward $(\mathrm{N})$ under conditions of odor maximization but not odor minimization. More specifically, when all animals received the same reward event on a given trial (i.e., $\mathrm{R}$ or $\mathrm{N}$ ), a pattern of running fast on $\mathrm{R}$ trials and slowly on $\mathrm{N}$ trials eventually appeared in the goal segment of a straight runway. When the runway was cleaned between animals, patterned responding disappeared, suggesting that odors can influence the behavior of subsequent conspecifics. Taylor and Ludvigson (1980b) have suggested that odors are present following both $\mathrm{R}$ and $\mathrm{N}$ treatments but the odor of nonreward appears to be the most salient (see also Prytula \& Davis, 1976).

Odors produced by animals traversing the runway appear to accumulate and display their most pronounced effects in the goal area (Ludvigson \& Sytsma, 1967; Prytula, Davis, \& Fanning, 1981; Seago, Ludvigson, \& Remley, 1970). However, Prytula and Davis (1976) have established patterning in the run and start measures by placing odor-donor subjects in selected areas of the runway. Further, it is of interest to note that $R$ and $N$ odor production and discrimination appear to be common across sexes (Eslinger \& Ludvigson, 1980) but that dissimilar deprivation states may well affect odor production and, therefore, the runway performance of the

This research was supported, in part, by a grant from the Research and Creativity Committee of Emporia State University to Stephen F. Davis. rat (Davis, Prytula, Harper, Tucker, Lewis, \& Flood, 1974; Davis, Prytula, Noble, \& Mollenhour, 1976).

Obviously, the presence of such uncontrolled odors poses tremendous potential problems for animal researchers. Uncontrolled, these odors certainly cast doubt upon the validity of many contemporary studies. Worse yet, literally decades of rat data may be based upon odorcontaminated testing. Given this state of affairs, it would appear to be of some importance to understand these odors as fully as possible. As indicated above, much is already known about the experimental conditions under which both the production and discriminative use of odors occur. Much less is known, however, about the source and/or specific nature of these odors.

McNeese and Ludvigson (Note 1) reported that the discriminable odor cue necessary for the development of patterned responding was not a function of the preputial gland or of the androgen-dependent accessory glands. Studies involving visible observation of urine and fluorescent emissions, as an indicant of urine (McNeese \& Ludvigson, Note 1), have also yielded negative results. More recently, Voorhees and Remley (1981) have demonstrated, through single-cell recordings of the rat olfactory bulb, that there are two specific (yet possibly similar in chemical structure) odors of $\mathrm{R}$ and $\mathrm{N}$ and that these odors are different from odors of food and urine.

All mammalian species commonly possess sweat glands that produce secretions under different physical and/or emotional conditions. Given that the odor of $\mathrm{N}$ is partially airborne but appears to be initially deposited on the apparatus flooring (Taylor \& Ludvigson, 1980a; 
McNeese \& Ludvigson, Note 1), and given that the rat possesses a footpad sweat gland, it would appear feasible to consider this specific gland as a possible source of $\mathrm{N}$ odor. The present study was designed to isolate the footpad sweat glands and investigate their possible role in odor production. If, in fact, the feet and this gland are sources of odor, then subjects should display nondifferential responding on all trials on which secretions from these sources are precluded.

\section{METHOD}

\section{Subjects}

Eight 90-day-old male Holtzman rats served as subjects. All animals were individually caged, with water available on a free-feeding basis.

\section{Apparatus}

A single, straight runway $(11.4 \mathrm{~cm}$ wide $\times 12.70 \mathrm{~cm}$ high), having a gray startbox $(28.10 \mathrm{~cm})$ and black run $(91.40 \mathrm{~cm})$ and goal $(30.50 \mathrm{~cm})$ sections, served as the experimental apparatus. Masonite guillotine doors separated the start and goal sections from the run section. A microswitch, located on the start door, three photoelectric beams (located $15.20 \mathrm{~cm}$, $92.40 \mathrm{~cm}$, and $116.80 \mathrm{~cm}$ beyond the start door), and three electronic timers (Lafayette, Model 80200) were arranged to yield start, run, and goal latencies on all trials. A plastic receptacle, recessed into the end wall of the goalbox, served as the goal cup. A thin sheet of transparent plastic covered the top of the apparatus to prevent the dissipation of odors.

\section{Procedure}

One week prior to the initiation of pretraining, all subjects were (1) randomly assigned a permanent running-order number (1-8) and (2) placed on a food-deprivation regimen designed to maintain them at $85 \%$ of their free-feeding body weights. A 4-day pretraining phase immediately preceded experimental testing. Handling and taming occurred on Pretraining Days 1-2, and each subject was given a 5-min exploration period in the unbaited apparatus on Days 3-4. Habituation to the $45-\mathrm{mg}$ reward pellets occurred in the home cage on all pretraining days.

All subjects received an eight-trial double-alternation schedule (RRNNRRNN) on all days of the experiment. Experimental testing was divided into three phases. Phase 1 was 14 days (112 trials) in length and served as a baseline for the establishment of odor-mediated double-alternation patterning. Phase 2 was 2 days (16 trials) in length. On Day 1 of Phase 2, two coats of fast-drying aerosol rosin (Quick Drying Adherent; Cramer Products, Inc.) was sprayed on the feet of each subject. The first coat was applied $30 \mathrm{~min}$ before testing. This allowed ample time for both coats to completely dry. On Day 2, a single coat of aerosol polyurethane (plastic-Formula-U polyurethane; Pactra Industries, Inc.) was applied to the feet of each subject $1 \mathrm{~h}$ prior to experimental testing. Phase 3 lasted 3 days (24 trials) and involved the testing of subjects in the same manner (i.e., feet uncovered) as was done in Phase 1.

During all three phases, an $R$ trial consisted of $1245-\mathrm{mg}$ reward pellets, and an $\mathrm{N}$ trial consisted of 20 -sec confinement to the empty goalbox. As mentioned, the subjects were run in a fixed order $(1-8)$ on all days of the experiment, with Trial 1 being administered to all subjects before Trial 2 was administered, and so forth. The apparatus was swabbed with a damp sponge and aired for $5 \mathrm{~min}$ after the completion of each trial by all subjects. Thus, Subject 1 was always tested in a clean, odorfree runway and essentially served as an odor donor for the remaining subjects.

\section{RESULTS AND DISCUSSION}

The start, run, and goal latencies for each subject for each trial were transformed to reciprocals and, when multiplied by the appropriate constant, yielded speed scores in meters per second. For purposes of statistical analysis and graphing, the daily speed scores for each subject were combined in the following manner: The first two trials were averaged to yield an $R_{1}$ composite score, the next two trials were averaged to yield an $\mathrm{N}_{1}$ composite score, and so forth. The transformed scores were subjected to a subjects by treatments ( $R$ vs. N) by days analysis of variance. The Newman-Keuls procedure was employed to evaluate specific comparisons. The last 3 days of Phase 1 (the point at which patterning had been strongly established in the goal measure) and Phases 2 and 3 were selected for graphing and statistical analysis. $^{1}$ Mean start and run speeds are shown in Figure 1, and goal speeds are shown in Figure 2.

The impression conveyed by these figures would appear to be rather clear-cut. Patterning was not established in either the start or run segment of the apparatus. Strong patterning was developed in the goal measure by the end of Phase 1 , accentuated during Phase 2, and returned to the prior Phase 1 level during Phase 3.

Statistical analyses were supportive of these visual impressions. Start- and run-measure analyses failed to yield significant effects. However, significant $R$ vs. $\mathbf{N}$

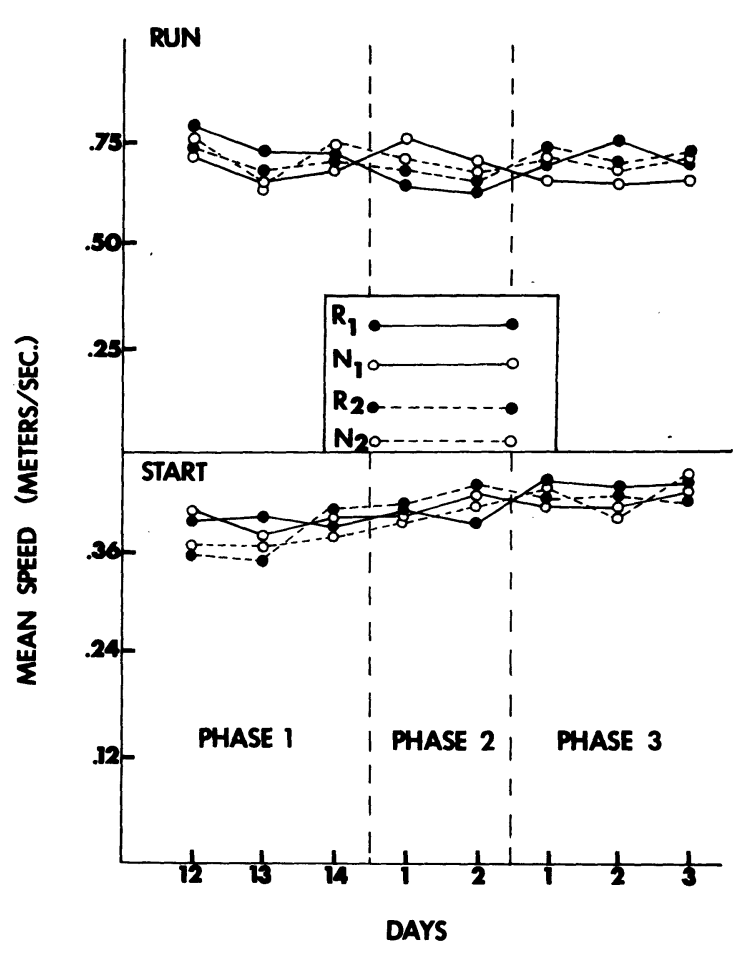

Figure 1. Mean start and run speeds (in meters per second) for the last 3 days of Phase 1, Phase 2, and Phase 3. 


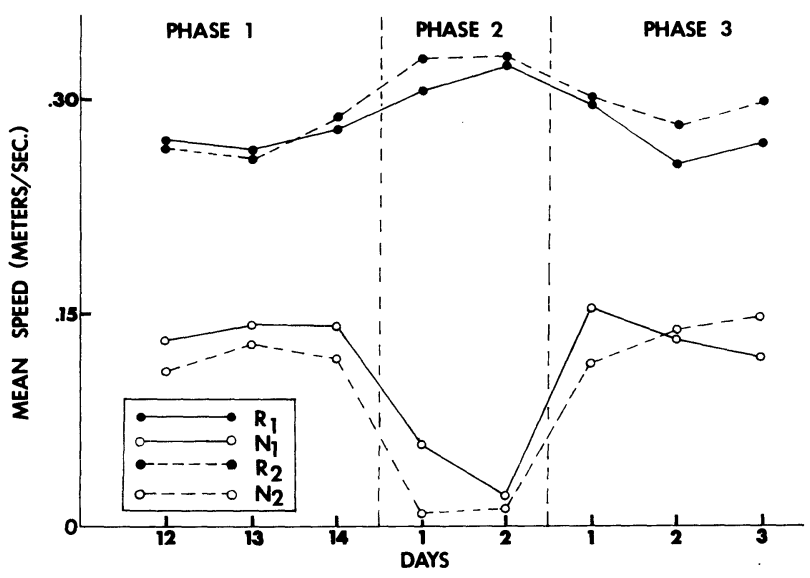

Figure 2. Mean goal speeds (in meters per second) for the last 3 days of Phase 1, Phase 2, and Phase 3.

$[F(1,90)=27.56, p<.01]$ and $R-N$ by Days $[F(7,90)=$ $2.45, \mathrm{p}<.05]$ effects were shown in the goal-measure analysis. Newman-Keuls tests indicated that all $\mathrm{N}$ speeds were significantly $(p<: 01)$ slower than all $R$ speeds. Further, it was found that $\mathrm{N}$ speeds on the 2 days of Phase 2 were significantly $(\mathrm{p}<.05)$ slower than all other $\mathrm{N}$ speeds.

Contrary to the initial considerations, these results suggest, rather convincingly, that $\mathrm{R}$ and $\mathrm{N}$ odors are not exuded via the feet or footpad sweat glands. Rather than eliminating $\mathrm{R}$ and/or $\mathrm{N}$ odors (i.e., reducing or precluding patterning), spraying the animals' feet with aerosol rosin and polyurethane (Phase 2) resulted in a significant intensification of patterned responding. The observation that both $\mathrm{N}$ and $\mathrm{R}$ trials were affected is supportive of the Prytula et al. (1981) and Taylor and Ludvigson (1980b) contention that there are two distinct types of odors. That N-trial speeds were more strongly affected than R-trial speeds during Phase 2 is supportive of the greater salience of $\mathrm{N}$ odors. Reestablishment of the unsprayed (Phase 1) condition during Phase 3 resulted in the return of patterning to the original, Phase 1, level. Thus, what precluding odors from the rats' feet appears to do is eliminate some form of natural animal odor that, in turn, serves to partially mask the odors of $\mathrm{R}$ and $\mathrm{N}$.

The lack of variation in the Phase 2 start- and runmeasure behavior indicates that the spraying operations affected goal performance via odor production rather than directly affecting general performance. This contention is further supported by the lack of change in the performance of Subject 1 from Phase 1 through Phase 3.

Even though the present study was not successful in isolating the feet and/or foot sweat glands as the source of $\mathrm{R}$ and $\mathrm{N}$ odors, it would appear to have eliminated them from consideration as potential sources. Moreover, the spraying technique employed in the present study seems to offer a viable procedure for further investigation of potential odor sources.

\section{REFERENCE NOTE}

1. McNeese, R., \& Ludvigson, H. W. Searching for the source of frustration odor. Paper presented at the meeting of the Southwestern Psychological Association, Houston, 1975.

\section{REFERENCES}

Davis, S. F., Prytula, R. E., Harper, W. E., Tucker, H. K., LEwis, C., \& Flood, L. Double-alternation runway performance as a function of inter- and intra-reinforcement odor cues. Psychological Reports, 1974, 35, 787-793.

Davis, S. F., Prytula, R. E., Noble, M. J., \& Mollenhour, M. N. Motivational specificity of the signal value of odor cues. Animal Learning \& Behavior, 1976, 4, 407-410.

Eslinger, P. J., \& Ludvigson, H. W. Commonality among rats in production of reward and nonreward odors. Bulletin of the Psychonomic Society, 1980, 16, 191-193.

Ludvigson, H. W., \& Sytsma, D. The sweet smell of success: Apparent double alternation in the rat. Psychonomic Science, 1967, 9, 283-284.

Prytula, R. E., \& Davis, S. F. The relationship between locus of odor cues and double-alternation responding in the rat. Animal Learning \& Behavior, 1976, 4, 352-356.

Prytula, R. E., Davis, S. F., \& Fanning, J. J. Acquisition of a running response as a function of odor buildup, squad rotation, and introduction of naive subjects. Animal Learning \& Behavior, 1981, 9, 556-560.

Seago, J. D., Ludvigson, H. W., \& Remley, N. R. Effects of anosmia on apparent double alternation in the rat. Journal of Comparative and Physiological Psychology, 1970, 71, 435442.

TAYLOR, R. D., \& Ludvigson, H. W. Selective removal of alleyway paper flooring to assess locus of nonreward odor. Bulletin of the Psychonomic Society, 1980, 16, 105-108. (a)

TAYLOR, R. D., \& Ludvigson, H. W. Selective removal of reward and nonreward odors to assess their control of patterned responding in rats. Bulletin of the Psychonomic Society, 1980, 16, 101-104. (b)

Voorhees, J. W., \& Remley, N. R. Mitral cell responses to the odors of reward and nonreward. Physiological Psychology, $1981,9,164-170$.

\section{NOTE}

1. Subject 1 was always tested in a clean, swabbed apparatus (i.e., served as an odor donor), the data from this animal were excluded from data analysis and graphs. Visual inspection of the scores for this animal indicated that it displayed stable, nondifferential performance during all phases of the experiment. 